\title{
PENINGKATAN TEKNIK SHOOTING MELALUI MODEL PEMBELAJARAN TEAM ASSISTED INDIVIDUALIZATION (TAI)
}

\author{
Muchamad Ishak \\ STKIP Pasundan Cimahi \\ E-mail: muchamadishak11@gmail.com
}

Diterima: 31 Oktober 2017; Lolos: 14 November 2017; Dipublikasikan: 14

Abstrak

Penelitian ini bertujuan untuk mengetahui kooperatif tipe Team Assisted Individualizatic belajar teknik shooting bagian pungg $\mathrm{g} \mathrm{k}$ Metode penelitian yang digunakan ad diambil adalah seluruh siswo berjumlah 51 siswa. Pend teknik cluster samplip dalam dua kelomp Individualizatio analisis eksperi perhitur tinggi $d$ pembel signifik dalam
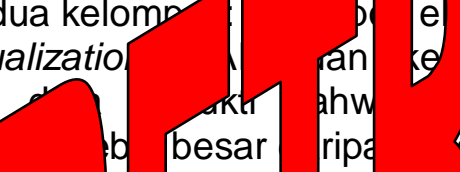

Kata
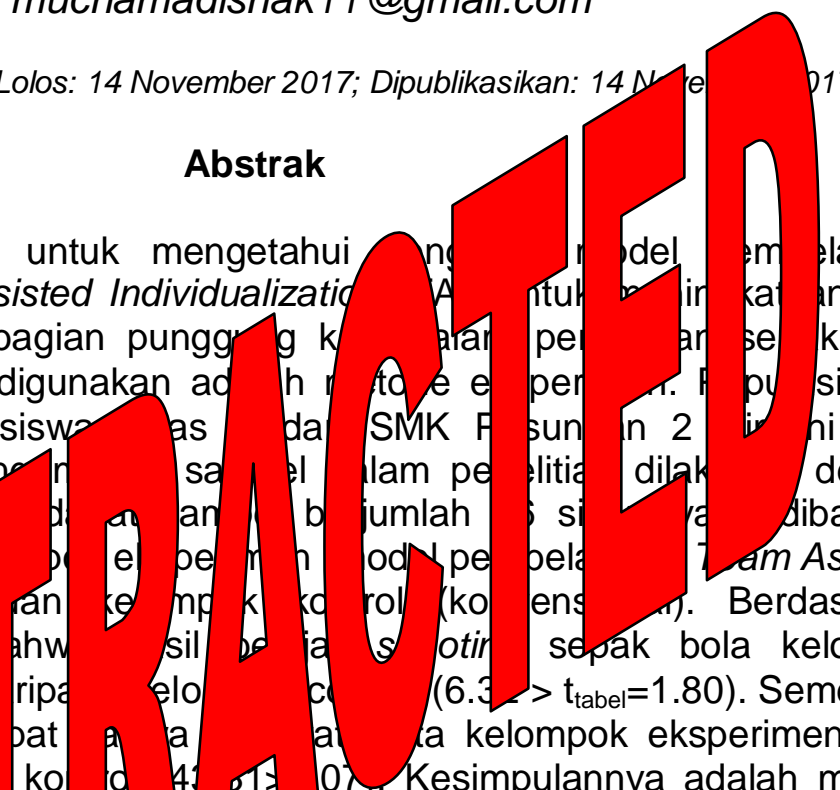
$\begin{array}{ll} & \\ \mathrm{ka} & \text { ajaran hasil } \\ \text { pe } & \mathrm{k} \text { bola. } \\ \text { pi yang }\end{array}$ hi yang dengan Aibagi ke am Assisted Berdasarkan otir sepak bola kelompok (6.3 $\left.>t_{\text {tabel }}=1.80\right)$. Sementara la kelompok eksperimen lebih Kesimpulannya adalah metode liza. on (TAI) memberikan pengaruh yang ajar teknik shooting bagian punggung kaki

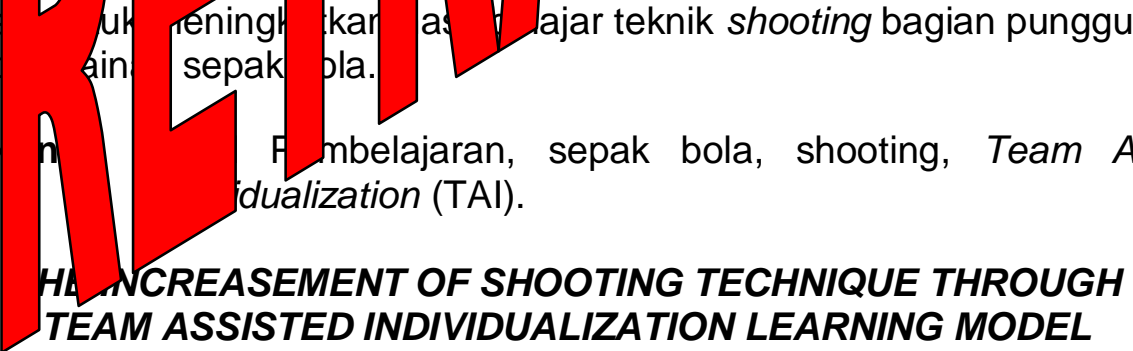

Abstract

The intention of this research is to know the influence of Team Assisted Individualization (TAI) learning model to increase students' shooting using instep part in football. The method of this research was experimental method. The population that was taken was the entire tenth grade students of SMK PASUNDAN 2 Cimahi consisted of 51 students. Using cluster sampling technique, it was obtained sample as many as 26 participants which were divided into two groups: experimental group (Team Assisted Individualization (TAI) learning model and control group (conventional). Based on the data analysis, students' shooting in experiment group is better than control group (6.32 $>t_{\text {table }}$ 1.80). Meanwhile, the statistical calculation showed the mean score of experiment group is bigger than control group (43.31>4.07). The conclusion is Team Assisted Individualization (TAI) learning method gives significant influence to increase students' shooting using instep part in football.

Keywords: Learning Model, football, shooting, Team Assisted Individualization (TAl).

Email : muchamadishak11@gmail.com

No Handphone : 085222332248
(C)2017 UN PGRI Kediri

p-ISSN: $2548-7833$

e-ISSN: $2477-3379$ 


\section{PENDAHULUAN}

Pendidikan jasmani adalah proses pendidikan yang memanfaatkan aktifitas fisik untuk menghasilkan perubahan holistik dalam kualitas individu, baik dalam hal fisik, mental, secara emosional. Juga dikatakan bahwa guru pendidikan jasmani mencoba mencapai tujuannya dengan mengajarkan dan memajukan aktivitas-aktivitas jasmani. dikan jasmani dapat didefinisikan sebagai pendidikan tentango erak insani, ketika tujuan kependidikan dicapai melalui stita otot, termasuk: olahraga (sport), permainan, s om atipa ja nani (exercise). Hasil yang ingin dicapai of lan jidy an cara fisik. Barrow dalam Abduljabar pos nila men di s ah s agian nilai individu yang terd dengan sisi kehidy diajarkan

Sucipto dkk (2000:7) berpendapat bahwa Sepak bola merupakan cabang olahraga yang sangat populer hampir diseluruh dunia. Demikian juga di Indonesia, sepak bola merupakan cabang olahraga yang paling digemari masyarakat. Terbukti dengan adanya klub-klub sepak bola yang mempunyai dan memiliki pemain yang berkualitas, itu jadi salah satu alasan olahraga sepak bola dimasukkan kedalam pembelajaran pendidikan jasmani disekolah. Disamping itu sepak bola juga merangsang lebih cepat motorik anak dan meningkatkan kebugaran jasmani dan dapat menanamkan jiwa-jiwa sosial. 
Rusman (2014:1) berpendapat bahwa Model-model pembelajaran merupakan keniscayaan yang harus di persiapkan dan di lakukan oleh guru dalam kegiatan pembelajaran. Guru merupakan ujung tombak keberhasilan kegiatan pembelajaran di sekolah yang terlibat langsung dalam merencanakan dan melaksanakan kegiatan pembelajaran. Kualitas kegiatan pembelajaran yang dilakukan sangat bergantung ada perencanaan dan pelaksanaan proses pembelajaran yang an guru. Tugas guru bukan semata-mata mengajar (teacb th pi lebih ke pembelajaran siswa (children centered) adalah proses interaksi terhadap semua sjtuas siswa.

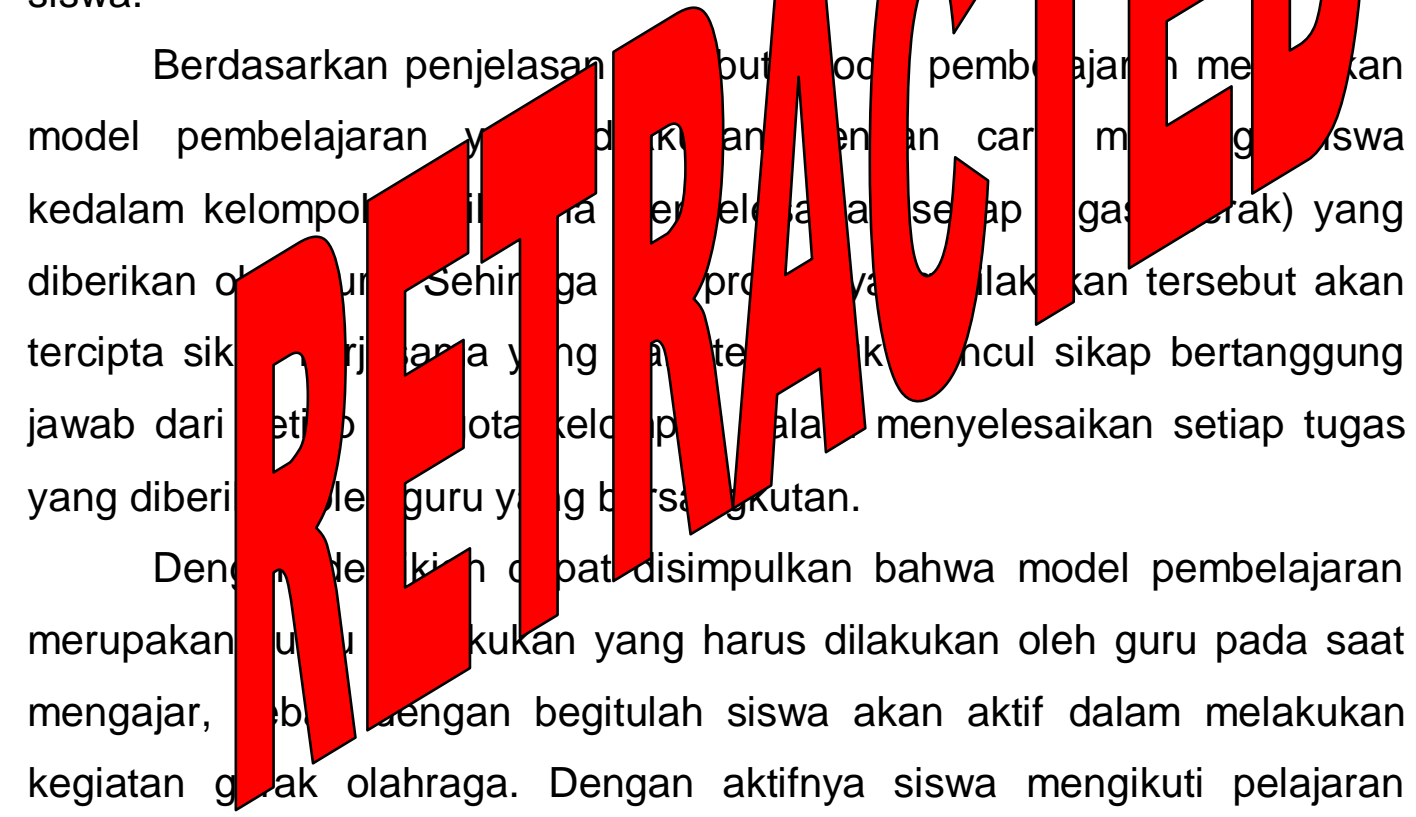
pendidikan jasmani, maka dengan sendirinya kesegaran jasmani pada siswa akan lebih baik dan dengan begitulah proses pembelajaran pendidikan jasmani akan terlaksana dengan baik.Sesuai dalam uraian diatas dibutuhkan model pembelajaran yang diharapkan mampu mengatasi kesulitan belajar siswa yang berbeda - beda

Menurut Robert Slavin (Miftahul, 2013: 200) Team Assisted Individualization merupakan sebuah program pedagogik yang berusaha mengadaptasikan pembelajaran dengan perbedaan individual siswa secara akademik, bahwa di dalam tipe TAI ini siswa belajar dari teman melalui belajar kelompok diskusi dan saling mengoreksi. Siswa diberi 
waktu lebih banyak berpikir, menjawab dan saling membantu satu sama lain. Dalam hal ini siswa yang lemah dalam mata pelajaran tidak segan untuk berdiskusi dengan siswa yang dianggap mampu. Dalam upaya meningkatkan hasil belajar siswa melalui penerapan model pembelajaran kooperatif tipe TAI ini diharapkan suasana belajar lebih menyenangkan, siswa lebih aktif dikarenakan siswa dapat belajar dan saling berdiskusi dengan teman kelompoknya.

Namun kenyataan yang dijumpai dilapangan, pendidikan jasmani dalam proses belajar mengajar m dan masih menggunakan gaya komando dalam sekolah maka dalam upaya meningkatan mencoba menerapkan pembelajary $\mathrm{kg}$ kooperatif ini adalah metode dalam pembelajaran sy

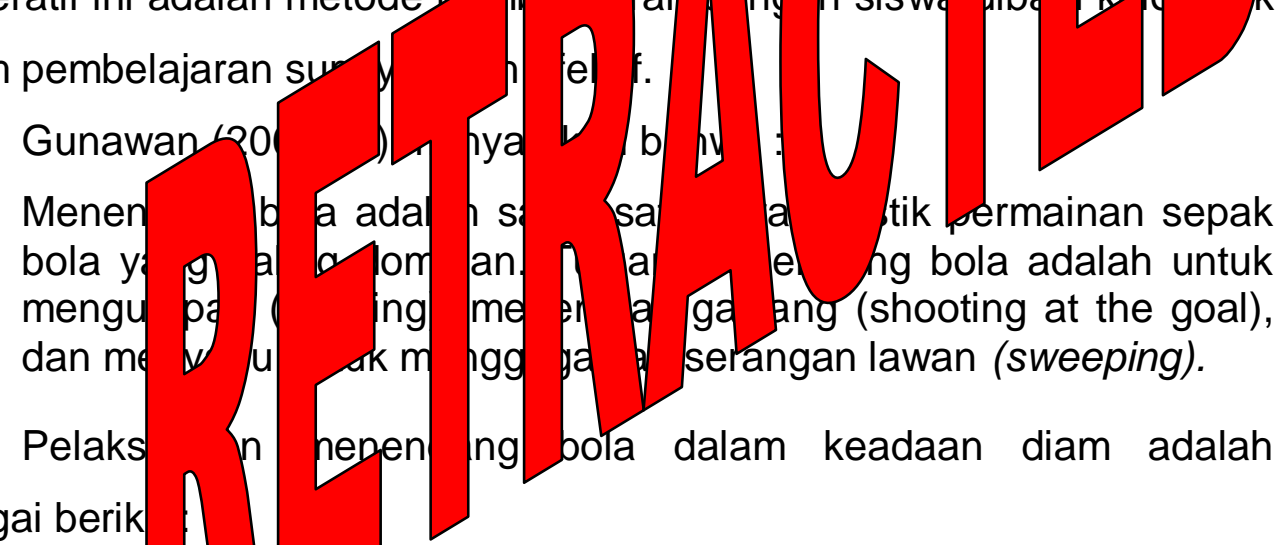
sebagai berik

1) $\mathrm{Kar}$

2) Tur kal kaki tumpu ditekuk $\pm 135^{\circ}$, sehingga berat badan berada pada kaki tumpu.

3) Ayun kaki tumpu ke belakang sehingga terjadi hiper ekstensi pada panggul, fleksi tungkai pada lutut, dan fleksi kaki pada pergelangan kaki.

4) Setelah mencapai hiper ekstensi maksimal pada panggul, kaki tending diayun ke depan secara eksplosif sehingga punggung kaki mengenai bola.

5) Perkenaan punggung kaki pada bola tepat pada bagian tengah bawah bola sehingga bola melambung dengan sudut elevasi $45^{\circ}$. 
6) Follow through, punggung kaki tending mengarah ke sasaran.

7) Pandangan mengikuti jalannya bola dan lengan menjaga keseimbangan.

Pada pelaksanaan menendang bola bergerak, prinsipnya sama hanya saja dibutuhkan ketepatan menempatkan kaki tumpu di belakang samping bola pada saat bola bergerak untuk ditendang. Bola bergerak bisa dari arah depan mendekati pemain, bisa sejalan dan penjauhi pemain, bisa dari samping kiri dan kanan pemain. Oleb $r$ untuk dapat melakukan gerakan tersebut dibutuhkan mata untuk melihat bola dan untuk mempg ik flakang samping bola dan kaki ayun untuk monen

Maka dengan demikian penelitian dengan judy/ Pembelajaran

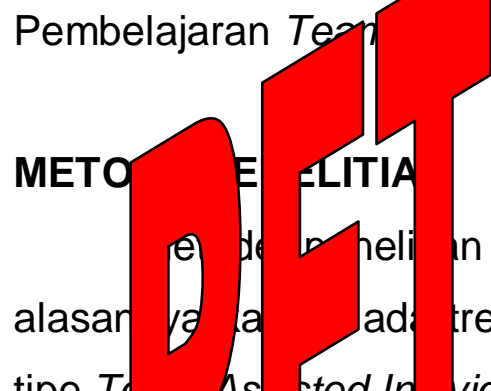
tipe $T$ SMK peneli 9 la 7 am enetitian ini adalah seluruh siswa-siswi kelas Xdari yang uJelaskan oleh Sugiyono (2015:65) yaitu "teknik sampling searah digunakan untuk menentukan sampel bila obyek yang akan diteliti atau sumber data sangat luas".

Menurut Surakhmad dalam buku Riduwan (2013:65) berpendapat apabila ukuran populasi sebanyak kurang lebih dari 1000, maka pengambilan sampel sekurang-kurangnya 50\% dari ukuran populasi. Apabila ukuran populasi sama dengan atau lebih dari 1000, ukuran sampel diharapkan sekurang-kurangnya $15 \%$ dari ukuran populasi. Penentuan jumlah sampel dapat dirumuskan sebagai berikut: 


$$
s=15 \%+\frac{1000-n}{1000-100} \cdot(50 \%-15 \%)
$$

Dimana :

$\mathrm{S}=$ Jumlah sampel yang diambil

$\mathrm{N}=$ jumlah anggota populasi

$$
\begin{aligned}
& s=15 \%+\frac{1000-51}{1000-100} \cdot(50 \%-15 \%) \\
& s=15 \%+\frac{949}{900} \cdot(35 \%) \\
& s=15 \%+1,05 \cdot(35 \%) \\
& s=15 \%+36,07 \% \\
& s=51,07 \%
\end{aligned}
$$

Jadi, jumlah sampel sebesar $51 \times 51$

\section{HASIL DAN PEMBAHA}

1. Hasil Penghi

dapat
baku

Dari data tersebut pada tabel 1 dapat dikemukakan sebagai berikut:

a. Kelompok pembelajaran TAI rata-rata tes awal sebesar 30.85 dengan simpangan baku sebesar 2.1, tes akhir sebesar 43.31 dengan simpangan baku sebesar 1.49 dan peningkatan hasil pemberian treatment sebesar 12.46 dengan simpangan baku sebesar 7.10 . 
b. Kelompok kontrol rata-rata tes awal sebesar 30.69 dengan simpangan baku sebesar 1.60,tes akhir sebesar 34.77 dengan simpangan baku sebesar 1.23, dan peningkatan hasil pemberian treatment sebesar 4.08 dengan simpangan baku sebesar 7.41

\section{Uji Normalitas Data}

Langkah selanjutnya ialah uji normalitas data. Uji ini dimaksudkan untuk mengetahui penyebaran dari distribusi data, apakah menyebar secara normal atau tidak. Hasil uji normalitas tersaji sebagai beriky

Tabel 2. Hasil Perhitungan Uji Normalitas dengan U

Kelompok Periode tes $\mathrm{L}$ hitung
Model
pembelajaran




\section{Hasil Perhitungan Uji Homogenitas}

Setelah dilakukan uji normalitas selanjutnya dilakukan uji homogenitas untuk mengetahui distribusi data homogen. Disebutkan untuk menguji hipotesis dengan menggunakan kesamaan dua rata-rata distribusi data harus normal dan homogen. Adapun hasilnya sebagai berikut:

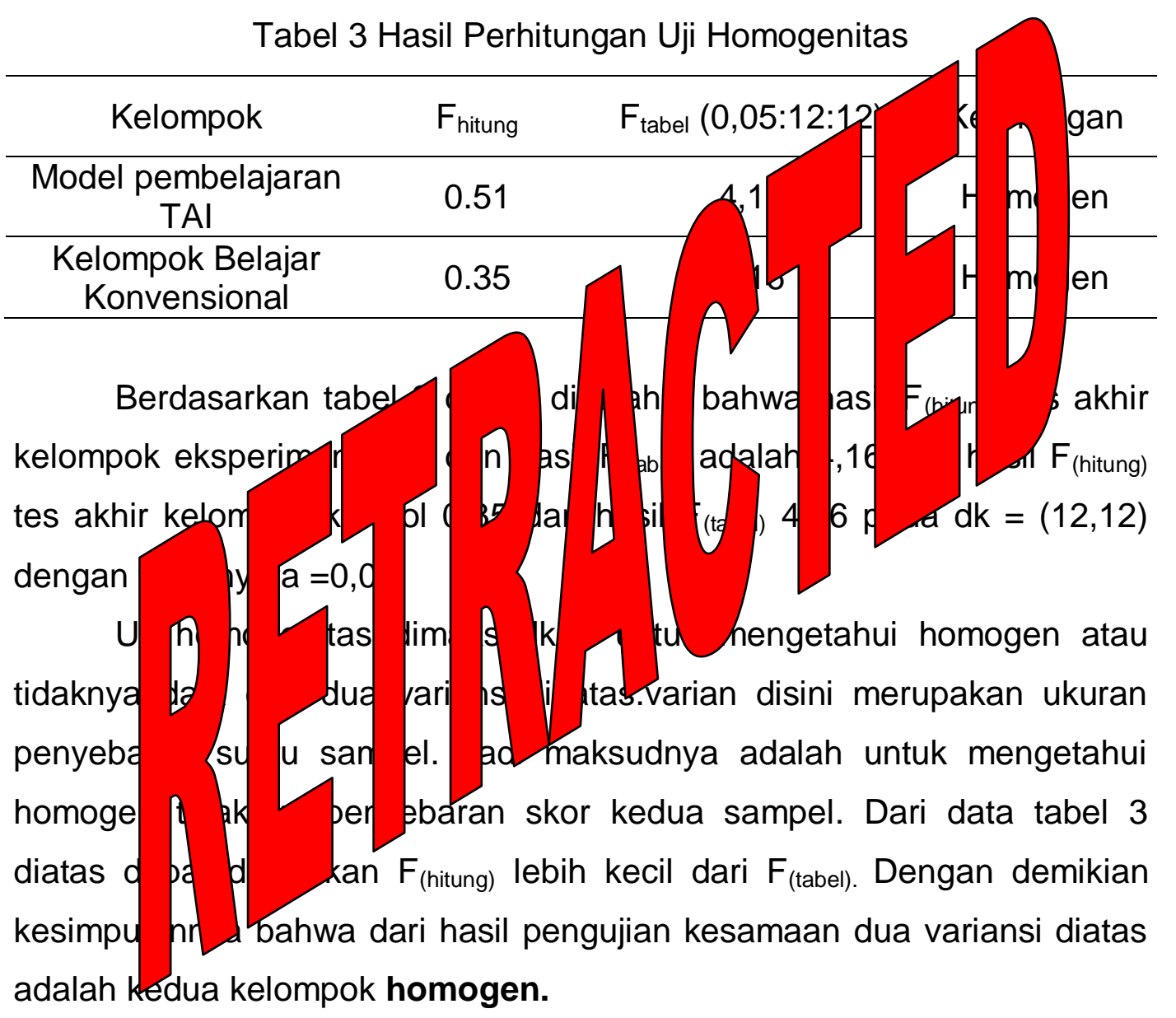

\section{Hasil Pengujian Signifikansi Peningkatan Kedua Kelompok}

Setelah selesai pengujian homogenitas selanjutnya menghitung peningkatan perbedaan kedua kelompok.hasil pengujian tersebut dapat dilihat pada tabel 4 berikut :

Tabel 4 hasil pengujian signifikansi peningkatan kedua kelompok

\begin{tabular}{cccc}
\hline Kelompok & $\mathrm{T}_{\text {hitung }}$ & $\mathrm{T}_{\text {tabel }}(0,05: 11)$ & Kesimpulan \\
\hline Eksperimen & 6.32 & 1,80 & Signifikan \\
\hline Kontrol & 1.98 & 1,80 & Signifikan \\
\hline
\end{tabular}


Dari hasil pengujian pada tabel 4 diperoleh bahwa $\mathrm{T}_{(\text {hitung) }}$ kelompok TAl 6.32 lebih besar dari $\mathrm{T}_{\text {(tabel) }}$ 1,80. Dan kelompok kontrol 1.98 lebih besar dari $\mathrm{T}_{\text {(tabel) }} 1,80$. Kriteria pengujian adalah tolak Ho jika $t_{\text {hitung }}>t_{\text {tabel }}$ pada taraf nyata $\alpha=0,05$ dengan $(\mathrm{dk})=(\mathrm{n}-2)=13-2=11$.dalam hal ini untuk kelompok eksperimen $\mathrm{T}_{\text {(hitung) }}$ tidak berada pada daerah penerimaan Ho,jadi Ho ditolak dan Hi diterima yang artinya terdapat pengaruh yang signifikan dari model pembelajaran TAl terhadap hasil belaiz shooting sepakbola dalam pembelajaran sepakbola. Sedangkan kelompok control thitung berada pada daerah penerimaan Ho ditolak yang artinya tidak terdapat pengaryh belajar konvensional terhadap hasil be pembelajaran sepakbola.

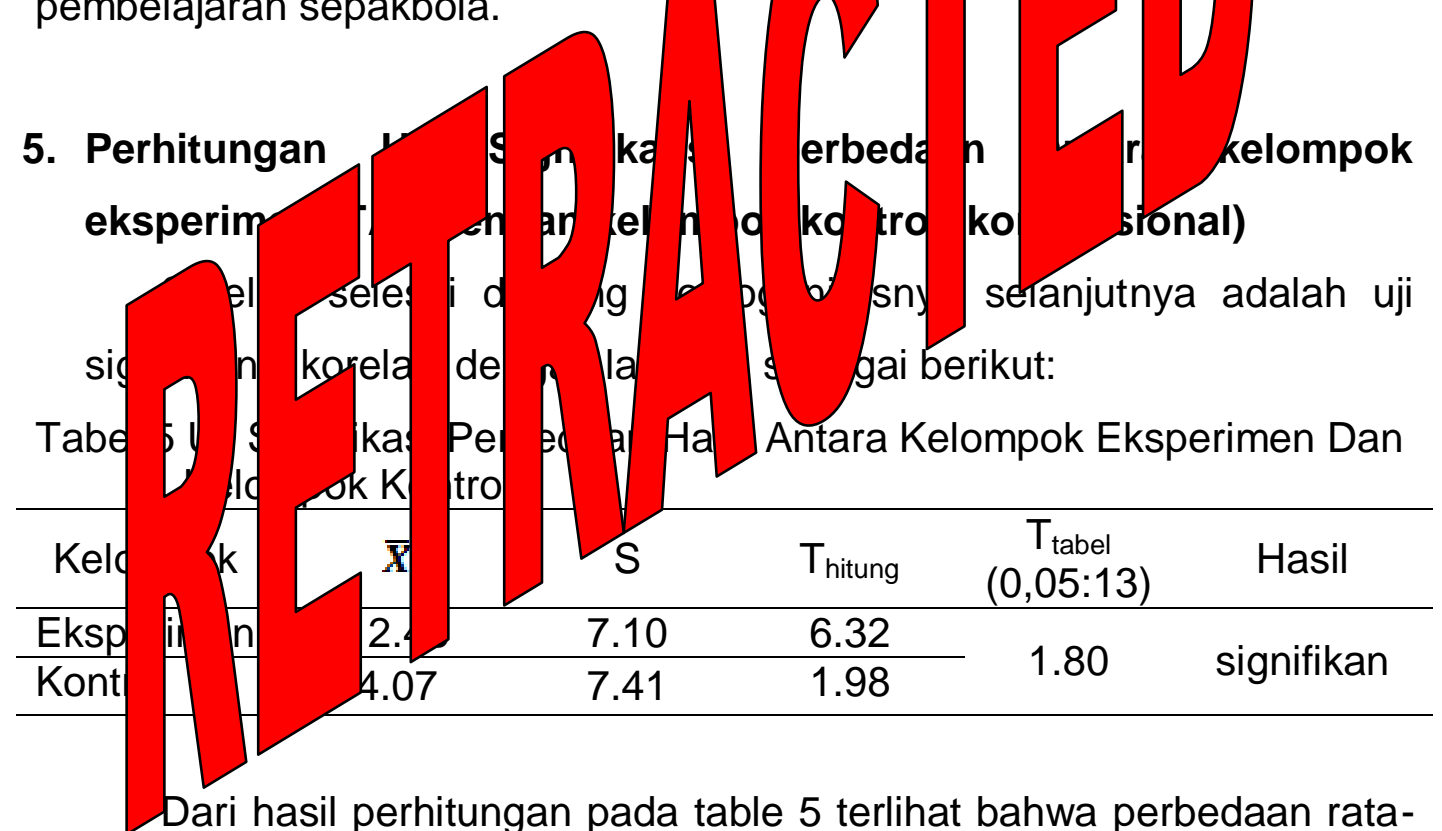
rata antara tes awal dan tes akhir terjadi secara signifikan terhadap kelompok A (model pembelajaran TAI) 12.46 di bandingkan dengan ratarata kelompok B (kelompok kontrol konvensional) 4.07 di SMK Pasundan 2 Cimahi. Selain itu terlihat juga nilai $S$ yang lebih besar dari t tabel (7.10 $>1,80)$. Dengan demikian hipotesis yang menyatakan bahwa ada perbedaan dari hasil metode pembelajaran antara kelompok eksperimen (TAI) dengan kelompok kontrol (konvensional) dapat ditolak.

Sesuai dengan tujuan penelitian yaitu untuk mengetahui seberapa besar Model kooperatif tipe Team Assisted Individualization (TAI) 
Berdasarkan data yang disajikan di atas maka peneliti menyimpulkan dari hasil penelitian ini adalah:

Berdasarkan hasil analisis data telah terbukti bahwa hasil belajar shooting sepakbola antara siswa yang mengikuti model pembelajaran kooperatif tipe "TAl" dengan teknik tutor sebaya lebih baik daripada siswa yang mengikuti model pembelajaran konvensional. Hal ini ditunjukkan dengan peningkatan sebesar $6.32>\mathrm{T}_{\text {(tabel) }} 1.80$ yang ternyata signifikan. Selanjutnya berdasarkan perhitungan statistik didapat bahwa belajar shooting sepak bola siswa yang mengikuti model pemb pperatif tipe "TAl" dengan teknik tutor sebaya memiliki a- a ebesar 43.31 lebih tinggi daripada hasil belajar s ti bo bola a yang mengikuti model pembelajaran kony psio drio me s pr ta-rata sebesar 4.07. Hal ini membuk tipe "TAl" dengan tol $r$ as terny a lab adel pembelajaran yay yg of el nem elai sensional. pembe a Pada o d p claj an o f tipe "TAl" dengan teknik tutor sebaya ini per aja $n$ difd isk sada siswa, dan perbedaannya dengan model a pe In jnvensional adalah siswa menjadi objek dalam pembe a $p$ a model pembelajaran kooperatif tipe "TAl" dengan teknik itd sebaya siswa sendiri yang terlibat dalam menyelesaikan segala permasalahan yang diberikan oleh guru, sehingga siswa yang kurang mampu akan dibantu oleh temannya yang sudah mengerti. Namun pada pembelajaran konvensional siswa yang kurang mengerti tidak bertanya kepada teman lainnya melainkan langsung kepada guru. Dalam penelitian ini, hal tersebut di atas yang diduga menyebabkan terjadinya perbedaan dalam hasil belajar shooting sepak bola siswa yang mengikuti kedua model pembelajaran tersebut.

Hasil belajar shooting sepak bola siswa yang mengikuti model pembelajaran kooperatif tipe "TAl" dengan teknik tutor sebaya lebih baik 
secara statistik jika dilihat dari hasil hasil belajar shooting sepak bola daripada siswa yang mengikuti model pembelajaran konvensional. Siswa yang mengikuti model pembelajaran kooperatif tipe "TAl" dengan teknik tutor sebaya rata-rata kemampuan teknik shooting sepakbola mereka lebih baik daripada rata-rata kemampuan teknik shooting sepakbola siswa yang mengikuti model pembelajaran konvensional. Setelah diketahui model pembelajaran kooperatif tipe "TAl" dengan teknik tutor sebaya lebih baik, dan berdasarkan hasil pengamatan peneliti bahw plengan menerapkan model pembelajaran kooperatif tipe "TAl" do kn tutor sebaya siswa merasa senang mengikuti sepakbola, lebih cepat memberi merespon

Siswa menjadi lebih berani kritis dalam adu pendapat, dapat mengalami kesulitan dengalaman dan
melakukan ba
penalar
dalam dipengaruhi oleh perkembangan proses mental yang digunakan dalam berpikir (perkembangan kognitif) dan konsep yang digunakan dalam belajar. Perkembangan merupakan proses perubahan yang terjadi sepanjang waktu kearah positif. Jadi perkembangan kognitif dalam pendidikan merupakan proses yang harus difasilitasi dan dievaluasi pada diri siswa sepanjang waktu mereka menempuh pendidikan termasuk kemampuan pembelajaran olahraga. Salah satu faktor yang dapat mempengaruhi perkembangan kemampuan pembelajaran olahraga 
adalah interaksi antara pengajar dan siswa. Siswa memerlukan suasana pembelajaran yang memberikan kebebasan dan rasa aman bagi siswa untuk mengekspresikan pendapat dan keputusannya selama berpartisipasi dalam kegiatan pembelajaran.

\section{KESIMPULAN DAN SARAN}

Berdasarkan hasil penelitian yang telah dilakukan serta perhitungan dan analisis data maka dapat disimpulkan bahwa pada kelompok eksperimen yang diberi perlakuan dengan model koopo at team assisted individualization (TAI) memberikan peno if क nifikan dibandingkan kelompok kontrol yang tidak dib erlak in engan model kooperatif tipe team assisted meningkatkan hasil belajar shoo permainan sepakbola pad sooperatif tipe penelitian ini, dianjurkan kepada rekan-rekan mahasiswa terutama jurusan PJKR untuk melakukan penelitian lebih lanjut, dengan permasalahan yang lebih luas dan sampel yang lebih banyak lagi.

\section{DAFTAR PUSTAKA}

Abduljabar. 2008. Pembelajaran Manajemen Pendidikan Jasmani dan Olahraga. Bandung: UPI.

Huda, Miftahul. 2013. Model-model Pengajaran dan Pembelajaran. Yogyakarta: Pustaka Pelajar 
Gunawan, Indra. 2009. Teknik Olahraga Sepakbola. Jakarta: IPA ABONG

Riduwan. 2013. Belajar Mudah Penelitian untuk Guru - Karyawan dan Penelitian Pemula. Bandung: Alfabeta.

Rusman. 2014. Model-Model Pembelajaran (Meng angkan Profesionalisme Guru). Jakarta: Raja Grafindo Pers?

Sucipto, dkk. 2000. Sepakbola. Jakarta: Depart for fir tan Kebudayaan.

Sugiyono (2015). Statistika Untuk Pepqlitia

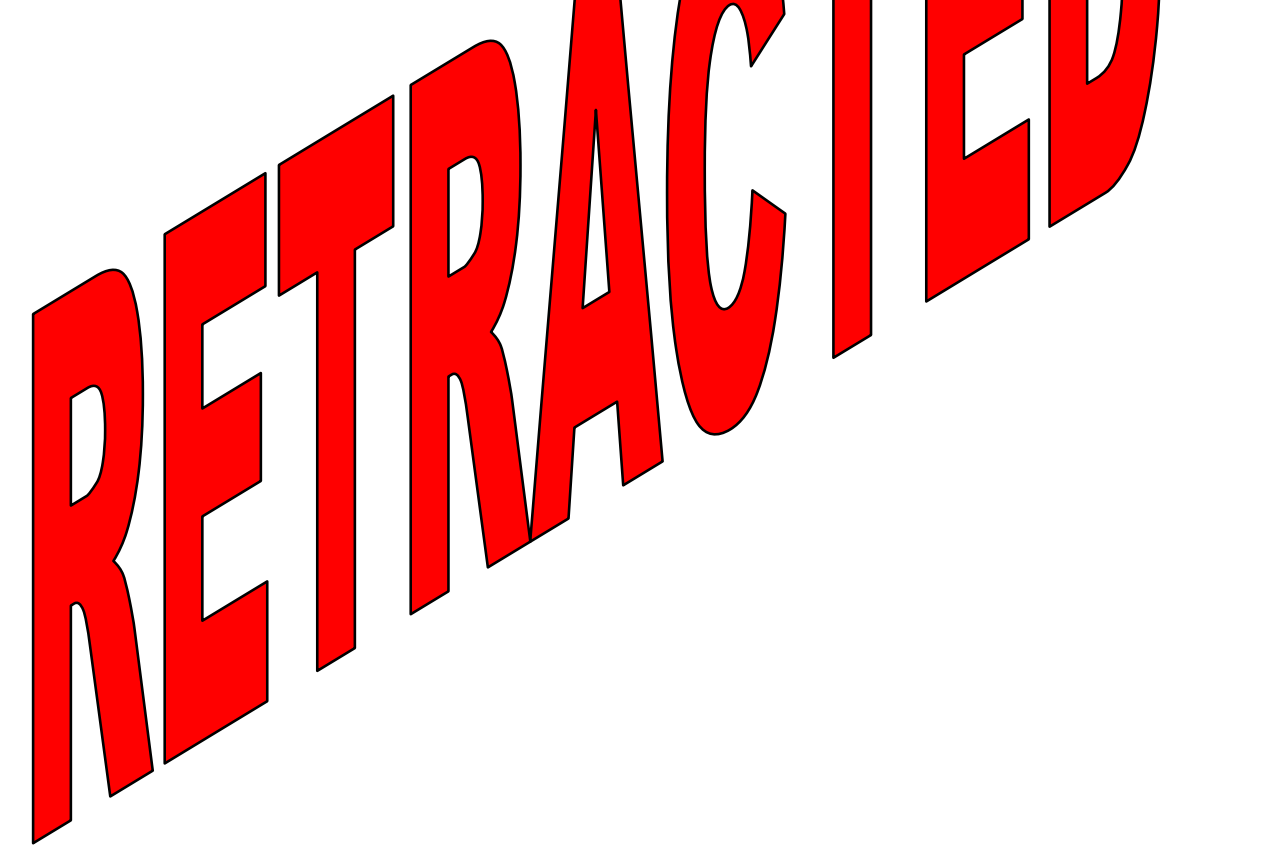

